\title{
Development of rural areas of a coal-mining region in the context of the creation of an agglomeration system
}

\author{
Vladimir Merkuriev ${ }^{1}$, Tatiana Yurzina $^{1}$, Piotr Kosinsky ${ }^{1}$, and Aleksey Kharitonov ${ }^{2}$ \\ ${ }^{1}$ T.F. Gorbachev Kuzbass State Technical University, Kemerovo, Russia \\ ${ }^{2}$ Siberian research institute of rural economics SFNZA RAN, Novosibirsk, Russia
}

\begin{abstract}
The article is devoted to the study of the problems of the development of rural agglomerations of a coal-mining region. It was revealed that the intensive development of the coal industry leads to negative consequences for the environment, which affect the socioeconomic development and the quality of life of the population of a region. The rural areas of the Russian Federation and each individual region are strategic resources, however, the lack of opportunity to meet their urgent needs, difficult living conditions of the rural population, isolation of rural settlements from scientific and technological achievements, poor development of transport infrastructure and communications do not allow unlocking the potential of rural areas. Analyzing the decisions made in recent years by the Government of the Russian Federation to regulate the development of rural areas and the agro-industry, we can conclude about a qualitatively new approach to state regulation of the agrarian sector. At the same time, the financial position of the overwhelming majority of the rural population does not allow contracting house construction mortgage loans. The level of improvement of the rural housing stock is 2-3 times lagging behind the urban one. Coal mining entails disturbance of land, which cannot be further used. It is accompanied by a high incidence of respiratory diseases and cancers, which tends to grow. The resources allocated for welfare programs do not allow the residents in rural areas to significantly improve their living conditions, to increase the availability of social services and their quality. To solve the identified problems, it is proposed to create rural agglomerations, allowing for more efficient and independent development of rural areas; to reduce the overlapping of management functions through streamlining management structures; implement a more equitable social policy for the residents of rural areas.
\end{abstract}

\footnotetext{
* Corresponding author: merkurevvv@,kuzstu.ru
} 


\section{Introduction}

Socio-economic transformations at the current stage of development of Russia are accompanied by significant changes in the conditions of economic entities of the rural economy, an increase in unemployment and a decrease in the incomes of residents living in rural areas. The wages of agricultural workers are significantly lower than the average wages in the country, which predetermines the growth of poverty in rural areas. Along with this, in many industrialized constituent entities of the Russian Federation, other sectors of the economy are developing quite intensively and dynamically, significantly affecting the development of rural areas. Such subjects include Kuzbass, in which economy the coal industry occupies a dominant position.

The establishment, development and activity of municipalities is considered as a phenomenon. However, the reform of local government system (LGS) and its results are positively assessed by only half of the heads of rural settlements.

Crisis phenomena in the economy and the resulting limited opportunities for resolving local problems of rural settlements lead to the low assessment of their heads. Insufficient financing of rural areas does not allow timely solving local problems and is a constraining factor in the development of local government system that shatters confidence in this institution. Low local tax rate collection restrains the budget revenues and calls into question the independence of local government bodies.

The development of rural areas is considered as an integral part of the state strategy for sustainable development, which presupposes the most optimal interaction: population - local government - industry and business. This trinity makes it possible to successfully develop an efficient municipal economy, including the economy of each rural settlement, which is an urgent task of managing the Russian economy.

The period of reforming local government system showed the insolvency and insufficient economic and financial security of many rural settlements, which does not allow them to fulfill the powers enshrined in legislation. The existing fiscal equalisation procedure deprives the rural municipality not only of financial independence, but also artificially subordinates it to the district authority. The current situation hinders the local government development and local community initiatives. It also exacerbates the relationship between municipal administrations and regional authorities. This circumstance hinders the implementation by local governments of the strategy of socio-economic development of rural areas in the interests of the population.

Creating the prerequisites and conditions for sustainable socio-economic development of rural areas of a coal-mining region, it is necessary to understand that a possible rational solution to the identified problems will only be a complete unification of all spheres and sectors of the regional economic structure, their even distribution within the agglomeration system.

However, the achievement of optimal results, in our opinion, is possible only through understanding the role and importance of rural development for a coal mining region.

\section{Results and discussion}

The traditional location of industrial facilities within the city limits affects rural areas mainly indirectly, but in the Kemerovo region with the intensive development of the industrial sector of the economy, the main of which is the coal industry, the situation is different.

The development of the coal industry, mainly located in rural areas, is more economically profitable in comparison with agricultural production. In addition, the coal industry is less dependent on weather and climatic conditions and seasonality. 
As a consequence, over the past decades, the specialization of production in the countryside has shifted from traditional agricultural activities to the dominance of the coal industry. The number of people employed at coal industry enterprises significantly exceeds the number of people employed in agricultural production.

In 7 rural settlements out of 18, the share of those employed in the coal industry is significantly higher than the average regional level. In some rural settlements of Belovsky, Kemerovsky, Novokuznetsky, Prokopyevsky districts, the share of the population employed in the coal industry is from 50.3 to 60.9 percent, with 14 percent on average in the region. At the same time, in recent years, this indicator has been stable both in the region and in municipalities.

The prevailing development of coal industry enterprises is most pronounced in Belovsky, Kemerovsky, Prokopyevsky and Novokuznetsky districts, which gives ground to refer to them as rural areas with an intensively developing coal industry. Note that coal production in Kuzbass increased from 164 million tons in 2005 to 249 million tons in 2019 one and a half times. It is assumed that in accordance with state plans, coal production will increase by one and a half times. The Kemerovo Region is a monoregion, where the dominant economic activity is coal mining and combustion.

Let us emphasize that the coal mining and processing industries of the regional economy generate more than 50 percent of the gross regional product. Statistical data confirm the economic benefits from the coal industry activities in comparison with other sectors of the economy. The population of these rural areas, employed in the coal industry, is 40 percent, the wages of people employed in industry are several times higher than the wages of those employed in agricultural production. The development of coal industry enterprises has a detrimental effect on the state of the environment in rural areas, and in terms of pollution it is comparable to industrialized urban areas.

Comparing the volumes of polluting emissions per inhabitant of rural and urban areas, it can be seen that the negative load on one rural inhabitant exceeds the load on the urban inhabitant more than twice. The increasing volumes of industrial production in rural areas create high environmental risks associated with the expansion of open pit coal mining, which contributes to an increase in emissions of pollutants into the air.

The high rate of emissions of pollutants into the air of cities and rural areas of the Kemerovo region indicates the equivalence of negative environmental consequences.

Coal mining leads to environmental stress, and, as a consequence, deterioration of the health of residents, accompanied by cancers and respiratory diseases. The development of the coal industry is important for the economy of the region and the creation of conditions that ensure social stability, however, it leads to serious environmental problems that affect people's health, as the most important component of the quality of life of the population. P.D. Kosinsky believes that the health of the population is a kind of indicator that characterizes the socio-economic situation both in the country and in individual regions.

The Kemerovo region is characterized by a high morbidity rate of the respiratory diseases and cancers, which tends to grow. In the Kemerovo Region, in 2019, the registered mortality rates exceed the average Russian level by 16 percent per 100 thousand of the population and amount to 1425.7 versus 1225.1 cases. The growth of malignant neoplasms affected the death rate of the population, which increased by 15.3 percent: from 208.9 in 2015 to 240.8 in 2019. Respiratory diseases contribute to high mortality, which over the past 30 years significantly exceeds the average Russian rate, amounting to 75.95 per 100 thousand inhabitants in Kuzbass and 58.98 in Russia.

Open pit mining endangers both people who directly work at coal mining enterprises and residents of the entire region. Open pit mining contributes to huge emissions of coal dust into the air, which is constantly inhaled by residents of rural and urban areas. Each mined ton of coal is accompanied by associated impurities in the amount of 3.82 kilograms, excluding gases, including radioactive ones. The volume of substances hazardous to humans 
is 280 kilograms per each Kuzbass resident and they grow with the increase in coal production.

Many experts directly associate the growth of cancers with an unfavorable environmental situation. The health status of residents of many rural areas of the region is alarming and predetermines the need to find ways out of the current situation.

Coal mining entails disturbance of land that cannot be used in the future. The areas mined land as of the beginning of 2020, according to the Ministry of Agriculture and Processing Industry of the Kemerovo Region, occupy 96.0 thousand hectares. In addition, coal mining, especially underground, leads to the formation of soil voids and sinkholes in soils, foundations, roads, which not only violates the eco-system, but can also be dangerous for people.

In our opinion, an effective solution to this problem can be the purposeful creation of agglomerations, which are now being created informally, or rather spontaneously, in rural areas of the Kemerovo region.

\section{Results}

Agglomeration systems play an important role in managing the development of rural areas, creating fundamentally new processes in the development of large territorial systems. In this regard, the interest shown by the authorities of the Russian Federation in the creation and development of agglomerations, including rural ones, is predetermined by the need to use new methods of ensuring territorial development aimed at increasing the efficiency of socioeconomic development of rural areas.

The French researcher Michel Rouget was the first to apply the concept of "agglomeration" to the settlement system. He argued that "agglomeration" is the spread of urban production to neighboring settlements.

Paul Krugman argued that agglomerations arise as a result of market regulation in conditions of increasing transport costs, and are a combination of more than two territorial structures with different economic areas.

However, until recently, the creation and development of rural agglomerations did not find wide attention from domestic scientists. In addition, the above concept itself was not enshrined in legislation.

The definition of rural agglomeration appeared in the State Program "Comprehensive Development of Rural Areas" for the period 2020-2025. (Resolution of the Government of the Russian Federation No. 696 of May 31, 2019). The state program "Comprehensive Development of Rural Areas" includes some of the existing measures and is supplemented by new ones. The main goals of the state program are the implementation of the following measures: improving the living standards of the rural population and its well-being, minimizing the difference in incomes of urban and rural residents; increasing the provision of up to 50 percent of rural residents with comfortable housing; maintaining the share of the rural population at least 25.3 percent in the total population of Russia.

Agglomeration means "rural areas, as well as urban-type settlements, workers' settlements that are not part of urban districts, and small towns with a population permanently residing in their territory not exceeding 30 thousand people".

In our opinion, such an approach is not entirely acceptable for the Kemerovo region due to the fact that rural settlements around small towns have "merged" with them geographically. And the intensively developing coal industry and industrial enterprises predetermine the consideration of rural agglomerations inseparably from small towns.

In addition, informal agglomeration processes are taking place in the region. As noted by a number of researchers studying the agglomerations - E.B. Alaev, S.A. Kovalev, I.V. 
Piletsky, A.I. Piletsky, Yu.V. Podoprigora, M.V. Shemyakina, S.I. Yakovleva. V.A. Shabashev et al., - rural agglomerations have features that confirm their informal existence.

These features include: "... the presence of a "coalescence" of neighboring settlements and their compactness, the shuttle migration, a transport network that allows 1-1.5 hour accessibility to city centers, the concentration of industrial production and labor resources, the existing close cultural, household and recreational ties, common labor, land and real estate markets, administrative and legal subordination and historically established economic dependence within the boundaries of the rural agglomeration area".

Agglomeration is accompanied by various savings: a decrease in transportation costs, economies of scale with an increase in production volumes by an individual enterprise or firm, infrastructural savings, which is an external impact on both an individual enterprise and the industry as a whole.

This type of savings is formed through the expansion and improvement of transport services, as well as commercial, financial services, an increase in the labor market and its flexibility, that is, the willingness and ability of workers to switch to other types of production.

Socio-economic development of territories in the form of agglomerations, in which resources are most efficiently used, a priori presupposes a positive effect - "agglomeration effect".

The relationship of agglomeration elements can be considered as complementary or subordinate.

The relationship between the core and the periphery is often characterized by unequal economic exchange. However, in the absence of the periphery, the meaning of the core is lost. The agglomeration core should be interested in the existence of the adjacent agglomeration space, which means that it should make efforts to ensure that the periphery grows qualitatively.

Thus, an agglomeration can be considered as a spatial market in which centrifugal and centripetal forces are present. At the same time, the economic space of the agglomeration may not coincide with the administrative territory. The agglomeration effect can, with a sufficient degree of probability, be calculated using economic and mathematical modeling

The effect of rural agglomeration can be assessed by several components, the most significant is the increase in gross value added as a result of territorial association:

$$
\mathbf{A E _ { a v }}=\mathbf{A V} \mathbf{V}_{\mathbf{a}}-\mathbf{A V _ { 0 }}
$$

where $\mathrm{AV}_{\mathrm{a}}$ - the added value of the products of the agglomeration participants; association.

$\mathrm{AV}_{0}$ - the added value of the products of the participants of municipalities before

The added value of the products of the agglomeration participants is calculated by the formula:

$$
A C a=\frac{\sum_{\mathrm{k}=1}^{\mathrm{n}} \mathrm{I}_{\mathrm{k}} S_{\mathrm{k}}+\sum_{\mathrm{k}=1}^{\mathrm{n}} \mathrm{S}_{\mathrm{n}+\mathrm{k}}}{1+\mathrm{d}}-\mathrm{S}_{2 \mathrm{n}+1}-\mathrm{S}_{2 \mathrm{n}+2}
$$

где $\mathrm{AVa}$ - the added value of the products of the agglomeration participants;

$I_{k}$ - investment performance indicator for the $k$-th type of product (goods, works, services);

$S_{K}-$ cost of purchased products (goods, works, services) of the $k$-th type, rubles;

$S_{n+k}$ - income from the sale of products (goods, works, services) of the $k$-th type, rubles;

$d$ - discount rate that takes into account the level of inflation, requirements of the investor's profitability and other risks for the entire period of the operation of the agglomeration. 


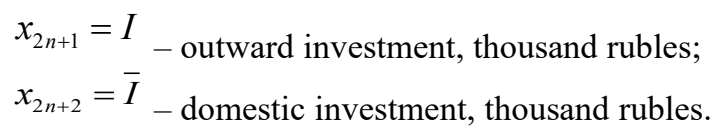

The results of model calculations are presented in the Table.

Table. Calculation of the agglomeration effect from the operation of the Leninsk-Kuznetsky rural agglomeration

\begin{tabular}{|c|c|c|c|c|c|}
\hline $\begin{array}{c}I_{k}- \\
\text { investment } \\
\text { performance } \\
\text { indicator }\end{array}$ & $\begin{array}{c}S_{\kappa}-\text { cost of } \\
\text { purchased } \\
\text { products } \\
\text { (goods, works, } \\
\text { services) }\end{array}$ & $\begin{array}{c}S_{n+k}- \\
\text { income } \\
\text { from the } \\
\text { sale of } \\
\text { products } \\
\text { (goods, } \\
\text { works, } \\
\text { services) }\end{array}$ & $\begin{array}{c}d \text {-discount } \\
\text { rate }\end{array}$ & $\begin{array}{c}x_{2 n+1}=I \\
\text { investment, } \\
\text { million } \\
\text { rubles }\end{array}$ & $\begin{array}{c}x_{2 n+2}=\bar{I} \\
- \text { domestic } \\
\text { investment }\end{array}$
\end{tabular}

The results of the model calculations for a municipality with $n=1$ and the agglomeration presented a value of 3.555 billion rubles, defined as the agglomeration effect. The presented model is universal. It can be used in the case when it is required to assess the agglomeration effect in the study of the economic feasibility of creating any agglomeration.

The calculation was carried out on the example of economic feasibility study of the creation of the Leninsk-Kuznetsk rural agglomeration.

Calculations show that the feasibility of creating rural agglomerations is confirmed by possible agglomeration effect, which will make the development of rural areas dynamic and sustainable.

\section{Conclusion}

Summarizing the above, we can conclude that Kuzbass is a typical coal-mining region, characterized by a significant industry influence on the efficient and independent development of rural areas. As a result, a deliberate policy of sustainable development focused on provodong economic well-being and resolving social problems of the rural population is required. It is necessary to make a transition to the development of rural areas at a completely new qualitative level, ensuring sustainability and comprehensiveness of development, using innovative procedures and modern tools for management decisions.

The solution to the problems of the development of rural areas of a coal-mining region revealed in the process of research can be the creation of rural agglomerations in accordance with the Comprehensive Program for the Development of Rural Areas in the Russian Federation for the period up to 2020-2025. The interest shown by the authorities of the Russian Federation in the creation and development of agglomerations, including rural ones, is predetermined by the need to use new methods of ensuring territorial development, aimed at increasing the efficiency of socio-economic development of rural areas.

The proposed method for determining the agglomeration effect confirms the economic feasibility of creating rural agglomerations. In addition to obtaining an effect, this will reduce the overlapping of management functions though streamlining management structures, and implement a more equitable approach to social policy. At the same time, 
rural areas and their development should be considered in conjunction with the general laws of the settlement system.

\section{References}

1. N. Zaruba, N. Egorova, P. Kosinskij, E3S Web Of Conferences 15, 04003 (2017)

2. E. M. Karataev, V. V. Merkuryev, O. V. Titova, Integrating the "Green Economy" into the Model of Digital Future of the Modern Socio-Economic Systems (Lecture Notes in Networks and Systems), 129 (2020)

3. V. G. Mikhailov, N. N. Golofastova, T. V. Galanina, T. G. Koroleva, Ya. S. Mikhailova. IOP Conf. Ser.: Earth Environ. Sci., 50:1, 012038 (2017)

4. P. Kosinskiy, V. Merkuriev, A. Medvedev, E3S Web of Conferences : The conference proceedings Sustainable Development of Eurasian Mining Regions: electronic edition, 03009 (2019)

P. D. Kosinskiy, V. V. Merkuryev, A. V. Medvedev, Coal in the 21st Century: Mining, Processing and Safety, 366 (2016)

5. R. L. Zakharchenko. Paul Krugman, HSE Economic Journal, 1, 130 (2009)

6. T. A. Yurzina, N.N.Yegorova, Economics and entrepreneurship, 8-1(85), 380 (2017)

7. Practical Guide IIA “Coordinating Activities and Leveraging Outputs: Mapping Safeguards” (Lake Mary, Florida: International Institute of Internal Auditors, 2018)

8. T. V. Kiseleva, V. G. Mikhailov, IOP Conference Series: Earth and Environmental Science, 012050 (2018)

9. V. G. Mikhailov, T. V. Kiseleva, V. A. Karasev, G. S. Mikhailov, V. A. Skukin. IOP Conf. Ser.: Earth Environ. Sci., 66:1, 012008 (2017)

10. M.-F. Rouge, Urbanisme, 60, 49 (1958)

11. N. Egorova, T. Jurzina, N .Zaruba, P. Kosinskij, E3S Web of Conferences The Second International Innovative Mining Symposium (2017)

12. T. Yurzina, N. Shalanov, P. Kosinskiy, E3S Web of Conferences. 5, 04057 (2020) 